\title{
The Rev. Father A. M. Tabard, M.A., M.B.E.
}

The study of history and archaeology in Southern India and Mysore has suffered a heavy loss by the death at Bangalore on 2nd July, 1926, of the Reverend Father A. M. Tabard. Father Tabard, who was in his sixty-third year, was a native of northern. France, and after the completion of his career as a student, was appointed a professor in Bangalore, where he passed the remainder of his life. Being a priest of the Roman Catholic Church, he was also chosen as Chaplain of St. Patrick's Cathedral, Bangalore, in which capacity he performed much valuable and ungrudging service for his parish. In conjunction with Mr. F. J. Richards of the Indian Civil Service, he was responsible for the foundation of the Mythic Society of Bangalore, which is affiliated to the Royal Asiatic Society, and devoted himself unsparingly to its advancement, placing it upon a sound financial basis, and providing it with a suitable library.

Father Tabard was the author of a treatise on the birth-place of Buddha and other works, while his minor antiquarian researches, coupled with his deep appreciation of the traditions, history and archaeology of Mysore, led to the conferment upon him by the Mysore Durbar of the title of Rajjasabhā Bhüshana, "ornament of the court." His long service to Mysore in other directions was rewarded with the Kaisar-iHind Gold Medal. The Royal Asiatic Society, of which Father Tabard was a member for sixteen years, shares the regret felt by the people of Mysore and the members of the Mythic Society at the loss of a scholar of sound judgment and sterling personality.

S. M. E. 